\title{
KRYTERIA JAKOŚCI W EWALUACJI PRZEKŁADU USTNEGO
}

Zarys treści: Poniższy artykuł jest próbą odpowiedzi na pytanie, czym jest jakość w przekładzie ustnym oraz jakie kryteria bierze się pod uwagę w procesie jej ewaluacji. Zaprezentowano wyniki znanych w literaturze przedmiotu badań empirycznych. Podkreślono kompleksowość zjawiska i trudność obiektywnej analizy, co prowadzić może do zaobserwowanego przez autorkę paradoksu związanego z rolą tłumacza w zapewnieniu przekładu odpowiedniej jakości.

\section{Wstęp}

N początku tego artykułu zaznaczmy, że pojęcie jakości w przekładzie ustnym jest kwestią złożoną; wątpliwości badaczy budzi również sposób i metoda jej oceny, a tym samym obiektywizm takiej ewaluacji. Ocena jakości przekładu od dość dawna znajdowała się w centrum zainteresowania (a zwłaszcza ocena jakości dokonywana przez uczestników procesu tłumaczeniowego). Treść przekazu w języku źródłowym powinna znaleźć swoje odzwierciedlenie $\mathrm{w}$ języku docelowym, a zatem komunikacja - skuteczna - pomiędzy słuchaczem (słuchaczami) a mówcą jest nadrzędnym celem przekładu ustnego. Nie będziemy w tym miejscu opisywać poszczególnych typów przekładu ustnego, ponieważ kwestia jakości odnosi się do wszystkich ich rodzajów, bez względu na sposób prezentowania informacji. Tłumaczenie ustne często przedstawiane jest jako złożona czynność werbalna o charakterze bilingwalnym, zorientowana na znaczenie, wykonywana pod presją czasu o kontrolowanym przez tłumacza tempie przetwarzania informacji (np. Chernov 1993, Gile 1995). Tłumaczenie ustne jest traktowane jako usługa komunikacyjna; 
$\mathrm{z}$ tej racji nie jest wykonywane w próżni, ale w określonym kontekście społecznym $\mathrm{z}$ określonymi grupami użytkowników. Tym samym tłumacz może uznać swoją „misję tłumaczeniową” za udaną, jeżeli umożliwi odpowiednią (satysfakcjonującą użytkowników) komunikację.

W tym miejscu należałoby krótko wspomnieć o różnych celach, jakie mogą mieć uczestnicy danego zdarzenia tłumaczeniowego: tłumacz świadczy usługi osobie zlecającej tłumaczenie, ale jego praca służy też zarówno mówcy, jak i słuchaczom. Cele i intencje wymienionych stron mogą być różne, np. zleceniodawca tłumaczenia może być zainteresowany wyłącznie komercyjną stroną przedsięwzięcia. Te czasami sprzeczne ze sobą cele mogą być obarczone pewnymi konsekwencjami, a tłumacz może się uwikłać w przymus bycia lojalnym wobec jednej ze stron (por. Kopczyński 1997). Można przyjąć, że tłumacz jest w dużej mierze neutralny - zmienia tylko osobę, której jest alter ego, niejako przenosząc swoją lojalność z jednej strony na drugą (por. Gile 1995). Oczywiście mogą czasem pojawić się pewne wątpliwości (np. funkcjonowanie tłumacza w zawodzie zależy od zleceniodawcy, a nie od mówcy), ale wtedy pojawia się czynnik nierozerwalnie związany z dobrym przekładem i skuteczną komunikacją, a mianowicie jakość, która będzie stanowić przedmiot naszych rozważań w dalszej części artykułu.

\section{Pojęcie jakości}

Pojęcie jakości stanowiło istotny punkt zainteresowań ze strony tłumaczy profesjonalistów (zob. podział na tłumaczy profesjonalnych i nieprofesjonalnych przedstawiony przez Kussmaula 1995), natomiast sama kwestia jakości przez wiele lat nie była przedmiotem szczegółowych rozważań. Nawet w Practical Guide for Professional Interpreters, opublikowanym przez AIIC (Association Internationale des Interprètes de Conférence) w 1982 r., o jakości mówi się jak o „czymś ulotnym, co każdy potrafi rozpoznać, ale nikt nie może opisać” (that elusive something which everyone recognises but no one can successfully define - Dollerup, Lindegaard 1994: 233). Podejmując próbę opisu jakości - poza oczywiście subiektywnymi odczuciami wynikającymi z naszego rozumienia znaczenia cech, jakimi powinien charakteryzować się dobry przekład i efektywna komunikacja - nie możemy zapomnieć o zwróceniu uwagi na trzy podstawowe czynniki, a mianowicie tłumacza (jako twórcy/producenta tekstu), proces przekładu i produkt będący wynikiem tego procesu i zaangażowania (oraz kompetencji) tłumacza. 
Tłumacz odpowiedzialny jest za jakość, która jest wypadkową nie tylko wiedzy językowej, ale także całej sfery pozajęzykowej, czyli tzw. wiedzy ogólnej. Wiedza ogólna to pojęcie niezwykle szerokie, obejmujące wiedzę kulturową (dotyczącą obu rzeczywistości językowych, ponieważ tłumacz musi funkcjonować w obu tych światach), umiejętność radzenia sobie w różnych okolicznościach (co jest niewątpliwie związane ze zdolnościami poznawczymi, takimi jak pamięć, umiejętność podejmowania decyzji i rozwiązywania problemów czy doświadczenie), a także umiejętność poruszania się w nowoczesnym świecie i korzystania z jego zdobyczy. Proces przekładu może obejmować nie tylko stricte komercyjne przygotowanie do realizacji zlecenia, ale także etapy procesu tłumaczeniowego rozumianego jako analiza zlecenia i przygotowanie merytoryczne tłumacza do danego zlecenia, zebranie potrzebnych informacji itd.

Przedmiotem podlegającym bezpośredniej ocenie z punktu widzenia jakości jest końcowy produkt przekładu. Jakość tę można mierzyć nie tylko na podstawie kryteriów językowych (które zostaną omówione na podstawie kwestionariuszy w dalszej części artykułu), ale również wymogów formalnych (takich jak np. fakt, czy dany tekst jest zrozumiały).

Wymagania dotyczące jakości powinny zależeć od celu danego zadania tłumaczeniowego, jednak należy pamiętać o różnych oczekiwaniach użytkowników tłumaczenia (Dejean le Feal zauważa, że końcowy produkt powinien wywoływać taki sam skutek na słuchaczach tłumaczenia, jak wystąpienie w języku oryginału wpływa na jego odbiorców; Dejean le Feal 1990). Czym innym są więc normy lub standardy narzucane na tłumaczy przez organizację zawodową (i odnoszące się do profesjonalizmu oraz etyki tłumacza), a czym innym określone standardy natury językowej bądź pragmatycznej (odwołujące się do komunikacyjnej, językowej czy poznawczej kompetencji tłumacza).

Ustalenie kryteriów jakości jest istotne z punktu widzenia relacji pomiędzy tłumaczem ustnym a odbiorcą tłumaczenia (zleceniodawcą czy słuchaczem; por. Pöchhacker 1994). Takie kryteria mogłyby wyznaczyć pewne standardy pozwalające na formułowanie ocen dotyczących pracy tłumacza ( $w$ rozumieniu produktu końcowego).

Pojęcie jakości pojawiło się $\mathrm{w}$ orbicie zainteresowań badaczy właściwie dopiero w ostatnich dwudziestu latach, a brak dokładnej i obiektywnej definicji był powodem wysuwania wielu różnych postulatów i propozycji. Gile na przykład zasugerował podejście metodologiczne, w którym produkt końcowy (czyli przekład) miał być poddany ocenie słuchaczy na podstawie kwestionariuszy, a stopień dokładności przekazanej treści miał być zbadany poprzez analizę nagrań tekstu źródłowego i docelowego (por. Gile 1995). Ba- 
dania empiryczne prowadzone były również przez takich badaczy, jak Bühler (1986), Kurz (1989, 1993), Marrone (1993), Kopczyński (1994), Moser (1995), Mesa (2000), Kadric (2000) czy Pöchhacker (2000). Należy zwrócić uwagę, że w badaniach empirycznych pojawiło się rozróżnienie na ewaluację jakości z perspektywy samych tłumaczy jak i z perspektywy użytkowników tłumaczenia (słuchaczy). Z podanych wyżej badań poniżej przedstawimy dwa kwestionariusze koncentrujące się na oczekiwaniach użytkowników, czyli badania Bühler (1986) i Kurz (1989), kwestionariusz Kopczyńskiego (1994), ze względu na obecne w nim odniesienia do roli tłumacza, oraz dla porównania - kwestionariusz Pöchhackera (2000) w celu analizy potencjalnych zmian, jakie zaistniały przez nieomal 20 lat w podejściu do jakości w przekładzie ustnym.

\section{Kwestionariusze}

Jak już wspomnieliśmy, kryteria jakości mogą podlegać ocenie zarówno ze strony tłumaczy, jak i uczestników zdarzenia tłumaczeniowego (użytkowników przekładu). W swoim kwestionariuszu Bühler (1986) starała się uzyskać odpowiedź na pytanie, jakie kryteria językowe i pozajęzykowe brane są pod uwagę przez tłumaczy ustnych. Kwestionariusz obejmował 16 kryteriów (zarówno językowych, jak i pozajęzykowych):

1. silny akcent,

2. przyjemny głos,

3. płynność wypowiedzi,

4. logiczna spójność wypowiedzi,

5. zgodność $\mathrm{z}$ treścią oryginału,

6. kompletność wypowiedzi,

7. poprawne użycie struktur gramatycznych,

8. zastosowanie poprawnej terminologii,

9. zastosowanie odpowiedniego stylu,

10. dokładne przygotowanie materiałów konferencyjnych,

11. wytrzymałość,

12. opanowanie,

13. miły wygląd,

14. rzetelność,

15. umiejętność pracy w zespole,

16. pozytywne opinie od uczestników konferencji/słuchaczy. 
Bühler poprosiła tłumaczy, członków AIIC, o hierarchizację powyższych kryteriów oraz zwrócenie uwagi na ich znaczenie dla kandydatów aspirujących do członkostwa w AIIC. Na czele hierarchii pojawiła się zgodność z treścią oryginału, a następnie logiczna spójność oraz kompletność wypowiedzi. Te czynniki wyprzedziły poprawne użycie struktur gramatycznych oraz zastosowanie odpowiedniego stylu. Na kolejnym miejscu pojawiło się zastosowanie poprawnej terminologii. Kryteria pozajęzykowe, związane z cechami osobowościowymi oraz etyką pracy tłumacza uznano za ważne, natomiast nie za najistotniejsze. Były to w kolejności: silny akcent, płynność wypowiedzi oraz przyjemny głos. Dotyczyło to także wytrzymałości, rzetelności oraz dokładnego przygotowania materiałów konferencyjnych, a tym samym w dużej mierze sprowadzało się do umiejętności pracy w zespole. Można zatem wyciągnąć wniosek, że jeżeli traktujemy tłumaczenie ustne jako pracę w zespole, to wymagania dotyczące jakości są spełnione, jeśli tłumacze w danym zespole wykonują swoją pracę najlepiej jak potrafią (zob. Bühler 1986: 233).

Badanie Bühler stało się inspiracją dla Kurz (1989 i 1993), która w swoim eksperymencie postanowiła pokazać, które konkretnie kryteria jakości są brane pod uwagę przez tłumaczy oraz jaką zajmują pozycję w hierarchii. Spośród prezentowanych wyżej kryteriów wybrała następujące:

1. silny akcent,

2. przyjemny głos,

3. płynność wypowiedzi,

4. logiczna spójność wypowiedzi,

5. zgodność $\mathrm{z}$ treścią oryginału,

6. kompletność wypowiedzi,

7. poprawne użycie struktur gramatycznych,

8. zastosowanie poprawnej terminologii.

Kurz przeprowadziła swoje badanie w formie kwestionariusza, którego głównym celem było znalezienie odpowiedzi na pytania dotyczące istnienia różnicy w ocenie kryteriów jakości przez tłumaczy i przez uczestników konferencji (słuchaczy), różnicy w ocenach tych kryteriów przez różne grupy użytkowników oraz weryfikacji kluczowego znaczenia kontekstu sytuacyjnego i komunikacyjnego w tłumaczeniu ustnym (Kurz 1989: 15). W wynikach badań możemy dostrzec różnicę w ocenie kryteriów jakości pomiędzy różnymi grupami użytkowników. Należy podkreślić, że tłumacze byli o wiele bardziej wymagający niż uczestnicy konferencji. Ponownie jak u Buhler najistotniejszym kryterium była zgodność z treścią oryginału, po której mamy w kolejności logiczną spójność wypowiedzi, poprawne użycie struktur gramatycznych, przyjemny głos i silny akcent. Poszczególne oceny różniły się 
jednak znacznie w zależności od oczekiwań użytkowników dotyczących tłumaczenia.

Kwestionariusz Kurz był w pewnym sensie reakcją na badanie przeprowadzone przez Bühler. Jeżeli zatem postrzegamy przekład ustny jako komunikację interlingwalną, to jakość tego przekładu można ocenić tylko poprzez porównanie z oryginałem - zarówno Kurz, jak i Bühler dążą do stworzenia definicji tłumacza idealnego i idealnego przekładu, idealnego w rozumieniu dostosowania do wszystkich surowych norm i reguł narzuconych albo przez organizację zawodową lub kontekst sytuacyjny w trakcie danego zdarzenia tłumaczeniowego. Bühler wysuwa postulat, że idealny tłumacz to ten, który zapewnia idealny przekład w określonej sytuacji w określonym celu (Bühler 1986: 233). Ponieważ cele przekładu są różne, zatem percepcja jakości tłumaczenia również wyrażona jest w różny sposób, ze względu na często rozmijające się - a przynajmniej odmienne - oczekiwania i potrzeby użytkowników (np. naukowy a specjalistyczny dyskurs w trakcie tłumaczenia). Bühler dodaje ponadto, że idealny tłumacz powinien mieć dobre nawyki zawodowe, umieć współpracować $\mathrm{z}$ innymi i dobrze pracować w zespole.

Inne badanie przeprowadził z kolei Kopczyński (1994), który - zainspirowany badaniami Kurz i Bühler - zaproponował własne kryteria jakości przekładu.

Badaniem objęto dwie grupy uczestników konferencji, a mianowicie słuchaczy niebędących delegatami i mówców. Ponadto wyróżniono trzy różne grupy zawodowe:

- grupa 1 - osoby zajmujące się szeroko pojętymi naukami humanistycznymi (filolodzy, historycy, prawnicy),

- grupa 2 - osoby zajmujące się naukami ścisłymi (inżynierowie, lekarze),

- grupa 3 - dyplomaci.

Kwestionariusz skierowany był nie do samych uczestników konferencji, a do osób, które brały w niej udział jako mówcy, słuchacze niebędący delegatami lub uczestnicy rozmów (negocjacji). Pytania w kwestionariuszu odnosiły się do trzech głównych kwestii, a mianowicie najważniejszej funkcji przekładu w trakcie tłumaczenia na konferencji, czynników najbardziej irytujących w trakcie tłumaczenia oraz roli tłumacza. W przypadku najważniejszej funkcji przekładu osoby ankietowane miały zhierarchizować takie czynniki, jak: przekazanie w tłumaczeniu ogólnej i szczegółowej treści oryginału, precyzja terminologiczna, styl, poprawne zastosowanie struktur gramatycznych, płynność wypowiedzi, dykcja oraz przyjemny głos.

Za przykłady czynników irytujących posłużyły niewłaściwa terminologia, niegramatyczne zdania, błędy stylistyczne, zdania niedokończone, brak 
płynności wypowiedzi, zła dykcja, monotonna intonacja, jednostajne tempo mówienia, przyspieszanie bądź zwalnianie tempa wypowiedzi w jej trakcie, zbyt ogólne lub zbyt szczegółowe przekazywanie treści oryginału.

Ostatnią kwestią w badaniu była ocena najwłaściwszej roli tłumacza, a więc odpowiedź na pytanie, czy tłumacz powinien być neutralny (a nawet niewidzialny), czy też jego obecność powinna być odczuwalna. Respondenci mieli za zadanie odpowiedzieć na następujące pytania: czy tłumacz powinien wczuwać się w intencje mówcy, czy powinien naśladować dynamikę wypowiedzi (tempo mówienia, gestykulację), czy powinien być niewidzialny czy wręcz odwrotnie, czy powinien poprawiać mówcę (jeżeli ten popełni błąd), utożsamiać się z intencjami czy może streszczać wystąpienie oraz czy może pozwolić sobie na dodawanie własnych wyjaśnień do wypowiedzi mówcy.

W wynikach badania po raz kolejny wyraźnie widać, że treść przekazu jest o wiele ważniejsza dla tłumaczy i odbiorców tłumaczenia niż forma. Następnym istotnym czynnikiem była precyzja terminologiczna, po której dopiero na trzecie miejsce wysuwała się forma (płynność wypowiedzi w przypadku mówców, a styl i płynność wypowiedzi w przypadku odbiorców). W przypadku odpowiedzi z podziałem na grupy zawodowe szczegółowe przekazywanie treści oryginału zwyciężyło nad precyzją terminologiczną. Można jednak zauważyć pewną różnicę w obrębie tych grup: osoby zajmujące się szeroko pojętymi naukami humanistycznymi preferowały poprawne zastosowanie struktur gramatycznych i styl, natomiast osoby zajmujące się naukami ścisłymi i dyplomaci za istotniejszy czynnik uznawały płynność wypowiedzi.

Jeśli chodzi o czynniki irytujące, to wybór padł na niewłaściwą terminologię. Jednakże wybory innych czynników nie były już tak jednomyślne mówcy zwracali szczególną uwagę na stopień dokładności tłumaczenia tekstu, natomiast odbiorcy koncentrowali się na niedokończonych zdaniach i poprawnym zastosowaniu struktur gramatycznych. W grupach zawodowych pierwsze miejsce zajęła niewłaściwa terminologia. Dla grup 1. i 3. kolejnymi irytującymi czynnikami były niedokończone zdania, natomiast dla grupy 2 . ważniejsze były w tym kontekście brak płynności i niewłaściwe użycie struktur gramatycznych.

Rola tłumacza w odczuciu zarówno mówców, jak i odbiorców polega na byciu niewidzialnym, dlatego też ich zdaniem tłumacz powinien naśladować tempo mówcy (nie odnosi się to jednakże do imitowania jego sposobu gestykulacji). Tłumacz może także poprawiać mówcę i dodawać własne wyjaśnienia (co stoi jednak w sprzeczności z rolą niewidzialnego „ducha”). Tłumacz nie powinien ponadto streszczać wystąpienia mówcy. Inną interesującą różnicą widoczną w odpowiedziach jest zgoda mówców na bycie poprawianymi, 
czemu zdecydowanie sprzeciwiają się odbiorcy. Przy podziale na grupy zawodowe, grupa 1. preferuje bardziej aktywną - obserwowalną - rolę tłumacza, natomiast najbardziej restrykcyjną grupą pod tym względem są dyplomaci (prawdopodobnie wynika to $\mathrm{z}$ ich zaangażowania $\mathrm{w}$ sytuacje bardzo formalne na różnych szczeblach).

W ostatnim opisywanym badaniu, obrazującym i koncentrującym się już wokół nowych zadań przekładu ustnego, jakie stawia przed tłumaczami przekład ustny środowiskowy - community interpreting (por. Tryuk 2006), Pöchhacker (2000) w kwestionariuszu zapytał pracowników służby zdrowia i opieki społecznej o kwalifikacje tłumaczy i próbę zdefiniowania ich roli. Spośród 10 kryteriów, takich jak m.in. kompetencja językowa i kulturowa, wiedza ogólna, wiedza specjalistyczna, kształcenie w kierunku tłumaczenia ustnego, neutralne zachowanie, dyskrecja i poufność, tylko te dwa ostatnie większość respondentów oceniła jako bardzo ważne. Ponad 60\% użytkowników uznała dodawanie wyjaśnień, upraszczanie wypowiedzi i streszczanie ich jako część obowiązków tłumacza; $62 \%$ oczekiwało od tłumacza wyjaśnienia odniesień kulturowych oraz niejasności. Analiza danych dostarczonych przez poszczególne grupy zawodowe (Pöchhacker wyróżnia lekarzy, pielęgniarki, terapeutów oraz pracowników opieki społecznej) pozwala dostrzec istotne różnice. Dla pielęgniarek rola tłumacza polegała na ogarnięciu większego spektrum kwestii niż dla lekarzy, natomiast pracownicy opieki społecznej widzieli w tłumaczu mediatora kulturowego (badanie na podobnej grupie zawodowej przeprowadził również Mesa 2000).

\section{Uwagi końcowe}

Z powyższych badań wynika, że jakość w tłumaczeniu ustnym może podlegać różnym ocenom z perspektywy subiektywnej, jednakże można w cytowanych badaniach (również tych, których $\mathrm{z}$ racji ograniczeń tego artykułu nie mogliśmy omówić) dostrzec kilka kryteriów, które niewątpliwie są kluczowe dla oceny jakości. Te kryteria to przede wszystkim dokładność wypowiedzi i jej zgodność z treścią oryginału, jasność i precyzja wypowiedzi. Dokładność i zgodność z treścią oryginału są związane w sposób bezpośredni ze wspomnianym powyżej podejściem do przekładu zorientowanym na produkt. Jasność i precyzja wypowiedzi (zastosowanie odpowiedniego stylu) $\mathrm{z}$ kolei wiążą się z tłumaczem występującym $\mathrm{w}$ roli twórcy/producenta tekstu; inną sferą jest proces przekładu, w którym jakość rozumiana jest jako skuteczna komunikacja. A zatem różne kryteria leżące u podstawy oceny jakości 
odnoszą się do różnych aspektów przekładu, poczynając od tworzenia tekstu, poprzez jego przekazywanie, aż do osiągnięcia ostatecznego celu komunikacyjnego. Nacisk na komunikację widoczny jest w badaniach Viezziego (1996), gdzie perspektywa skutecznej komunikacji w przekładzie ustnym opiera się na czterech głównych celach, a mianowicie równoważności (ekwiwalencji), precyzji, odpowiedniości oraz użyteczności. Powyższe cele wynikają z natury przekładu ustnego, który jest przede wszystkim usługą świadczoną przez (1) profesjonalistów, (2) aktem komunikacji oraz (3) aktem działalności interlingwalnej i interkulturowej (Viezzi 1996).

Do wspomnianych wyżej cech odnosi się również Pöchhacker (2002), postulując cztery główne filary przekładu dobrej jakości, czyli precyzję, dokładność, równoważność (ekwiwalencję) oraz skuteczność (komunikacyjną). Jakość realizowana jest zatem w domenach informacji, kontekstu, funkcji i interakcji.

W badaniach przeprowadzonych na przestrzeni dwóch dekad można zaobserwować zarówno analizy zorientowane na produkt przekładu (w przypadku tłumaczenia ustnego, gdzie produkt przekładu postrzegany jest jako rezultat kompetencji tłumacza), jak i badania skoncentrowane na przekładzie środowiskowym, gdzie nacisk kładzie się na umiejętności i kwalifikacje tłumacza, co wyraźnie widać np. w badaniach Pöchhackera, który zalicza do nich kompetencję językową i kulturową, wiedzę ogólną i specjalistyczną, wspomniane powyżej dyskrecję, neutralne zachowanie i umiejętność tłumaczenia ustnego wynikającą z uzyskanego wykształcenia. Nadal jednak trwa dynamiczny proces poszukiwania profesjonalnych standardów postępowania i trudno przewidzieć, kiedy realizacja tego procesu dobiegnie końca, czyli kiedy będziemy mogli ustanowić jednolite kryteria oceny jakości przekładu. Jakość uznawana jest za konstrukt wielopłaszczyznowy i w dużej mierze jednak względny, niezależnie od tego, czy koncentrujemy się na produkcie przekładu, czy świadczonej przez tłumacza „usłudze komunikacyjnej”. Jakość można (i należy) zatem oceniać za pomocą zróżnicowanych metod, mając na względzie różne potrzeby, perspektywy i oczekiwania użytkowników tłumaczenia. Jakość nie jest zatem pojęciem samodzielnie i niezależnie funkcjonującym integralną rolę odgrywają w niej tekst, zgodność przekładu z oryginałem, skutek komunikacyjny oraz rola tłumacza.

Z przedstawionych powyżej analiz wynika zatem, że w trakcie ewaluacji procesu tłumaczeniowego należy brać pod uwagę fakt, że przekład ustny per se jest zjawiskiem przybierającym różne formy w różnych (społecznych) kontekstach. Niemożliwe jest więc zredukowanie jakości do warstwy wyłącznie językowej; ma ona miejsce także na poziomie komunikacyjnej interakcji 
w określonych kontekstach sytuacyjnych (por. Wadensjö 1998). Empiryczne badania nad jakością muszą więc koncentrować się na różnych aspektach tłumaczenia. We wspomnianych $\mathrm{w}$ artykule badaniach założenia badaczy dotyczące oczekiwań użytkowników tłumaczenia przynoszą rezultaty w postaci wyników, w których badani raczej koncentrują się na tym, co wydaje im się istotne w przekładzie ustnym. Badania zajmujące się ewaluacją jakości wydatnie pokazują, jakie czynniki w rzeczywistości kształtują pozytywne wrażenia użytkowników odnoszące się do pracy tłumacza w danym zadaniu tłumaczeniowym. Ma to znaczenie zwłaszcza w sytuacji, kiedy postrzeganie związanych $\mathrm{z}$ jakością cech tłumaczenia podlega sporej subiektywnie odczuwanej zmienności. Należy również zauważyć, że często kryteria jakości proponowane w kwestionariuszach są w znacznym stopniu nieostre; ich granice konceptualne nie są wyraźnie zaznaczone i w percepcji wielu ankietowanych są wzajemnie ze sobą powiązane (np. może być nam trudno wyraźnie oddzielić zgodność sensu z treścią oryginału od logiczności i kompletności wypowiedzi). Problematyczne staje się więc w tym wypadku określenie konkretnych parametrów jakości, niebudzących żadnych wątpliwości ani ze strony użytkowników tłumaczenia (np. słuchaczy), ani też samych tłumaczy. Jeżeli rolą tłumacza jest $\mathrm{z}$ jednej strony dochowanie absolutnej wierności tekstowi oryginału oraz bycie neutralnym (niewidzialnym), a $z$ drugiej strony powinien być kulturowym mediatorem całkowicie panującym nad komunikacją, ułatwiającym ją, dokonującym zmian w tekście na rzecz precyzji, jasności i sensowności przekazu, to mamy niewątpliwie do czynienia z pewnego rodzaju paradoksem. Ta sytuacja w pełni pozwala nam uzmysłowić sobie, jak bardzo złożoną i trudną do ostatecznej, obiektywnej analizy jest jakość w przekładzie ustnym.

\section{Literatura}

Bühler, H., 1986, „Linguistic (semantic) and extra-linguistic (pragmatic) criteria for the evaluation of conference interpretation and interpreters", Multilingua 5, 4, s. 231-235.

Bowen, D. i M. (red.), 1990, Interpreting: Yesterday, Today and Tomorrow, American Translators Association, Vol. 4, Binghamton.

Chernov, G., 1994, „Message redundancy and message anticipation in simultaneous interpreting", [w:] Bridging the Gap. Empirical research in simultaneous interpretation, Lambert, S., Moser-Mercer, B. (red.), Amsterdam 1994, s. 139-153. 
Dejean le Feal, K., 1990, „Some thoughts on the evaluation of simultaneous interpretation", [w:] Interpreting: Yesterday, Today and Tomorrow, Bowen, D. i M. (red.), American Translators Association, Vol. 4, Binghamton 1990, s. 154-160.

Dollerup, C, Lindegaard, A., 1994, Teaching Translation and Interpreting 2 Insights, Aims, Visions, Amsterdam-Philadelphia.

Gile, D., 1995, Basic Concepts and Models for Interpreter and Translator Training, Amsterdam-Philadelphia.

Hung, E. (red.), 2002, Teaching Translation and Interpreting 4 - Building Bridges, Amsterdam-Philadelphia.

Kadric, M., Kaindl, K., Pöchhacker, F. (red.), 2000, Translationswissenschaft, Tübingen.

Kopczyński, A., 1994, „Quality in conference interpreting: Some pragmatic problems", [w:] Bridging the Gap. Empirical research in simultaneous interpretation, Lambert, S., Moser-Mercer, B. (red.), Amsterdam 1994, s. $87-100$.

Kopczyński, A., 1997, „Praktyka i teoria tłumaczenia ustnego”, Neofilolog, 14, s. 17-26.

Kurz, I., 1989, „Conference Interpreting: User Expectations”, [w:] Coming of Age: Proceedings of the $30^{\text {th }}$ Annual Conference of the American Translators Association, Hammond, D. L. (red.), Medford-New Jersey, s. 143-148.

Kurz, I., 1993, „Conference Interpretation: Expectations of different user groups", The Interpreter's Newsletter, 5, s. 13-21.

Kussmaul, P., 1995, Training the Translator, Amsterdam-Philadelphia.

Lambert, S., Moser-Mercer., B. (red.), 1994, Bridging the Gap. Empirical research in simultaneous interpretation, Amsterdam.

Marrone, S., 1993, „Quality: A Shared Objective”, The Interpreter's Newsletter, 5, s. 35-41.

Mesa, A.-M., 2000, „The Cultural Interpreter: An Appreciated Professional. Results of a Study on Interpreting Services: Client, Health Care Worker and Interpreter Points of View", [w:] The Critical Link 2: Interpreters in the Community, Roberts, R. P., Carr, S. E. (red.), Amsterdam-Philadelphia, s. 67-79.

Moser, P., 1995, „Simultanes Konferenzdolmetschen. Anforderungen und Erwartungen der Benutzer. Endbericht, im Auftrag von AIIC", Wien.

Pöchhacker, F., 1994, „Quality assurance in simultaneous interpreting”, [w:] Teaching Translation and Interpreting 2 - Insights, Aims, Visions, Dollerup, C., Lindegaard, A. (red.), Amsterdam-Philadelphia 1994, s. 33-242. 
Pöchhacker, F., 2000, „The Community Interpreter's Task: Self-Perception and Provider Views", [w:] The Critical Link 2: Interpreters in the Community, Roberts, R. P., Carr, S. E. (red.), Amsterdam-Philadephia, s. 49-65.

Pöchhacker, F., Schlesinger, M. (red.), 2002, The Interpreting Studies Reader, London-New York.

Riccardi, A., 2002, „Evaluation in interpretation”, [w:] Teaching Translation and Interpreting 4 - Building Bridges, Hung, E. (red.), Amsterdam-Philadelphia, s. 115-126.

Roberts, R. P., Carr, S. E. (red.), 1997, The Critical Link 2: Interpreters in the Community, Amsterdam-Philadephia.

Snell-Hornby, M., Pöchhacker, F., Kaindl, K. (red.), 1994, Translation Studies: An Interdiscipline, Amsterdam.

Tryuk, M. 2006, Przekład ustny środowiskowy, Warszawa.

Viezzi, M., 1996, Aspetti della Qualita in Interpretazione, Trieste.

Wadensjö, C., 1998, Interpreting as Interaction, London-New York.

\section{Quality criteria in interpreting evaluation (summary)}

Translation quality evaluation has been in the focus of interest of researchers for quite a long time, although empirical investigations were started only two decades ago. The general assumption is that the source language message should be ideally manifested in the target language, thus effective communication between the listeners (users) and the speaker is the priority of translation/interpretation. Effective communication is enabled by means of good quality interpretation. In the attempt aimed at quality description, apart from subjective impressions resulting from our perception of the features that good translation/interpretation and effective communication should have, we cannot ignore three basic factors, i.e., the interpreter (as the text author/ producer), the interpretation process and product which is the result of this process and involvement as well as competence on the part of the interpreter/translator.

Quality criteria are largely fuzzy; their conceptual limits are not distinctive and, in the opinion of research subjects, are interrelated. Therefore, the specification of quality criteria that do not raise any doubts both on the part of users (e.g. listeners) and on the part of interpreters becomes problematic. The paradox of quality may emerge if the interpreter's role is, on the one hand, to retain absolute fidelity to the original text and his/ her neutrality (or invisibility), and on the other to be a cultural mediator who controls communication, facilitates it and corrects the text to make it accurate, clear and coherent. 